\title{
Children of Kampung Naga as The Representatives of Generation without Technology
}

\author{
Fatiha Khoirotunnisa Elfahmi \\ Universitas Pendidikan Indonesia, Bandung, Indonesia \\ e-mail: elfatiha@student.upi.edu
}

\begin{abstract}
Nowadays, in digital era, it becomes not possible to keep children away from information media and the sophisticated technology. This causes the child development becoming not optimal especially in several aspects including religious value, cognitive development, language development, motoric physical development and emotional social development in children. In fact, early age of children aged 0-8 years are commonly referred to the golden age, where children must be stimulated optimally in order to grow well until adult. On the other hand, the researcher found a traditional village that was not introduced directly to technology, so the author was interested in analyzing the development of the children in that traditional village. The method used in this study was comparative, to find out the differences the development of child when they are introduced with technology directly and indirectly. The result of the research showed that many local wisdoms were still maintained and taught by each parent to their children from early age through various traditional games and spending free time without technology. This has a very good impact on the factors of child development. Certainly, it can be reflection of parents in educating early childhood in the digital era today.
\end{abstract}

Keywords: Absence of technology, children development, early childhood, kampung naga

\section{INTRODUCTION}

Nowadays, the access of media information and technology is very easy and affordable for everyone. Even in general, children become active users in utilizing the advancement of information and technology media at this time.

According to Republika.com, children are often frustrated if they are kept away from gadgets. They have dependence on one of latest breakthroughs in this era of globalization. They cannot be separated from gadget when they are studying, eating even when they are sleeping. In fact, early childhood is not the time to know gadgets, children still need wider interaction with their peers, story books, color pencils, and so on.

Gadget is as two sides of coin that has two impacts both positive and negative on the child developments. The existence of various applications or shows that displays the recognition of letter, number, animal, fruit and so on certainly has a positive impact on children. However, once the students acquaint the gadget, the negative effect of it will be huge. The ease of information and technology media causes the children to become lazy to move and in daily activities. Playing gadgets too long also will damage eye health of the children. They are more interested in playing gadget than playing with their peers. Even the most fatal impacts are caused by the inappropriate show that often affect moral degradation in children.

Not only gadget that recently favored by the children, but internet and television also have an influence on them. Internet provides huge information freely. Even television's content that exists these days consists of inappropriate content which is not worthy for the children. 
In this digital era, it becomes inevitable to keep children away from information media and the sophisticated technology. However, in reality, there is one indigenous tribe in Indonesia that is not introduced to technology directly, a tribe located in Tasikmalaya - West Java - Indonesia where there is no technology in the environment that can be accessed by society in general.

This phenomenon occurred since the citizen of Kampung Naga still maintain the tradition of the ancestor. Be faithful to the ancestor is the rules of the tradition that must be adhered to. Thus, the children in Kampung Naga are a picture of a generation without technology. They spend their time to play with peers, family, and not introduced to the technology such as gadgets, television shows, and other activities such as accessing free content on the internet as what the society did nowadays. Certainly, this can build a strong foundation to develop the characters of the children as generation, alo ng with the appropriate attitudes and mindsets that reflects the characters of Indonesia. There are many values in the local wisdom in this village that can be used as an introspection for real life where it should be exemplified by the people of Indonesia.

Based on the research background above, the researcher is interested in this field of study especially in observing the development of the children in Kampung Naga compared to children in the city in terms of the gadget and the environment.

\section{METHOD}

This research was a result of comparative study as an outcome of theoretical

research. The method used in this study was comparative method. Comparative deductive method is a way to produce useful information about the nature of phenomenon. According to Nazir (2005: 58) Comparative method can be defined as a descriptive research that wants to look for the basic of causality by analyzing factors of the occurrence or the emergence of certain phenomenon.

\section{RESULT AND DISCUSSION}

\subsection{Social \& Cultural study of Kampung Naga}

Kampung Naga is one of villages in Indonesia where the sustainability of it is still maintained. This traditional village which holds the local wisdom closely is located in Neglasari village, Salawu, Tasikmalaya, West Java Province.

Kampung Naga maintains its customs when the surrounding society has changed by the time flies. Its presence illustrates the real life of Indonesian people who have not been contaminated by cultural changes. As an indigenous people of Kampung Naga, the society grow relative slowly over the past decades since they fortify their way of life with strong customary rules.

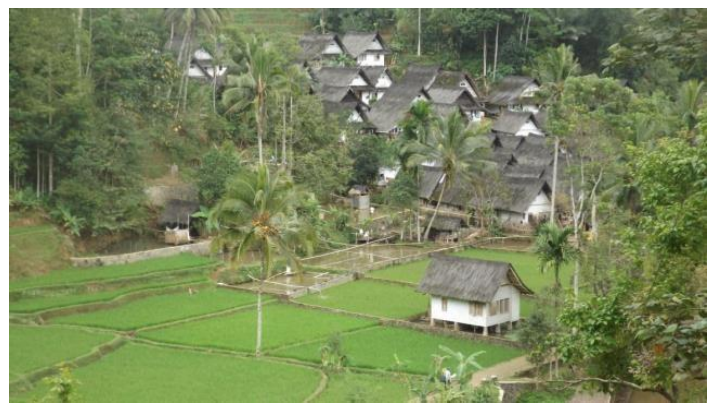

The society of Kampung Naga holds on the tradition carried out by their ancestor as the guidance of life including the values, norms, knowledge and rules as a belief that if they violate the traditions then it will encounter disaster.

In the society of Kampung Naga, the values of local wisdom education are carried out in an integrated manner between traditional institutions, communities and in the family environment (informal). In fact, the personality of the Kampung Naga society has universal values that are reflected in living various aspects of life including act locally, think globally and contribute to the formation of the nation's cultural identity as an embodiment of the integrity to the nation (commit nationally). All of that is applied by each parent to the child from an early age.

\subsection{The Social Environment of Children}

Environment is very influential for the development of children's character. In the process of child development, the environment is a very important factor after the gene factor. Social environment can also be called as community environment. The environment where the child lives can have an influence on the environment but on the contrary, the child can also receive influence from the community environment.

Community environment can play a role in shaping children's character. For example, the 
neighborhood where children live in urban areas that are introduced directly to the technology can cause addiction to gadgets. Internet influences the children to become lazy and lack their interaction in the surrounding environment, such as not knowing each other's neighbors. This kind of environment can create bad characters in the children. Children become accustomed to being insensitive to others, to feel they don't need other people in their lives, then to become individual. However, the results of the researcher's observation in the social environment of children in Kampung Naga showed the opposite. It consists of a large area to play traditional games, the intensity of children and parents' relationship is maintained, the values of the environment are vivid, dynamic, religious, and harmonious. This is because there is no direct introduction of technology which can shape the character of children such as politeness, easy to adapt to the environment, empathy, and becoming a human with high social values.

\subsection{Technology development in Kampung Naga}

One of the technological developments that cannot be accepted by the Kampung Naga community is the electricity. The parents in Kampung Naga believe that if the electricity goes into a settlement that has 113 traditional houses, their life will change. There are no electricity and technology except cellphones to receive news from relatives who have left the village.

\subsection{The influence of the absence of technology on the development of children in Kampung Naga}

The absence of the influence experienced directly by the children in Kampung Naga is because there is no technology such as electricity and internet networks.

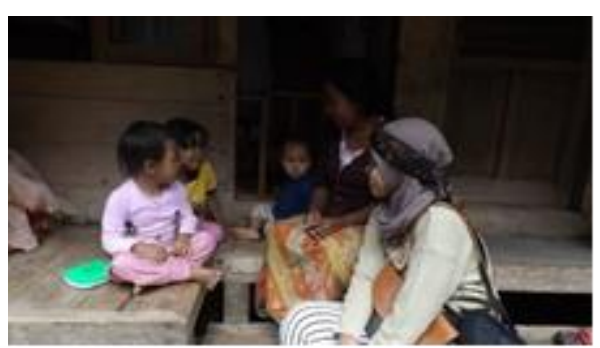

Thus, there are many positive influences when there is no direct introduction of technology there, those are;

- Religious values development activities

$\checkmark$ Habitual activities at home

such as evening recitations with their parents

$\checkmark$ Children starting from the

age of 3 years have begun routine recitation with the teacher of the Koran

$\checkmark$ Religious additional school

for children 7 - 13 years old.

Benefits: the formation of polite character will grow gradually

- Language development activity

$\checkmark$ Parents teach the children through errorcorrect system, that is when the children mispronounced the words, the teacher immediately corrected or especially the everyday language used was Sundanese

Benefits: memory and the right stimulus in the form of long term memory for children because the teaching error system is correct.

- Physical-motoric development

$\checkmark$ Traditional games in

Kampung Naga are among others (1) Gatrik (2) Gampar (3) Beklas (4) Congklak dan (5) Kasti. There are differences between boys and girls. Girls tend to play a game that trains the fine motoric like congklak dan beklas while for boys tend to play a game that trains rough motoric skills like gatrik, gampat and kasti. These traditional games could stimulate children's physical- motoric development well.

Benefits: children have strong endurance to adulthood.

- Social-emotional development activities

$\checkmark$ Children in Naga Traditional

village was accustomed to the arrival of tourists or new people into their village area. The children could socialize well when meeting tourists or new people.

Benefits: be sensitive to the environment and be tolerance to others

\section{CONCLUSION}

The study concluded that there are several differences in children who grow close with 
technology and grow without technology. Those who grow with technology often grow up with poor characters, such as being insensitive to the surrounding environment, not knowing each other's neighbors, and very individualistic. Differ from the children who grow up close with technology, the opposite creates the characteristics such as politeness, easy to adapt environment, empathy, even can hold the high social values as human being till they grow up

\section{REFERENCES}

[1] Patimah. (2000). Ensiklopedia Sunda. Jakarta.PT Pustaka Jaya

[2] Ameliola, Syifa \& Nugraha, Hanggara. (2013) Perkembangan Media Informasi dan Teknologi Terhadap Anak dalam Era Globalisasi. 